\title{
New Perspectives on West Africa and World War Two
}

\section{Introduction}

\author{
Oliver Coates \\ University of Cambridge, Cambridge, uk \\ orc2o@cam.ac.uk
}

\begin{abstract}
Focusing on Anglophone West Africa, particularly Nigeria and the Gold Coast (Ghana), this article analyses the historiography of World War Two, examining recruitment, civil defence, intelligence gathering, combat, demobilisation, and the predicament of exservicemen. It argues that we must avoid an overly homogeneous notion of African participation in the war, and that we should instead attempt to distinguish between combatants and non-combatants, as well as differentiating in terms of geography and education, all variables that made a significant difference to wartime labour conditions and post-war prospects. It will show how the existing historiography facilitates an appreciation of the role of West Africans in distinct theatres of combat, and examine the role of such sources as African war memoirs, journalism and photography in developing our understanding of Africans in East Africa, South and South-East Asia, and the Middle East. More generally, it will demonstrate how recent scholarship has further complicated our comprehension of the conflict, opening new fields of study such as the interaction of gender and warfare, the role of religion in colonial armed forces, and the transnational experiences of West Africans during the war. The article concludes with a discussion of the historical memory of the war in contemporary West African fiction and documentary film.
\end{abstract}

\section{Keywords}

World War Two - Africa - West Africa - Asia - warfare - military - military labour historical memory 
World War Two represented 'more of an assumption than a reality' contended Rathbone and Killingray in their pioneering volume arising from a 1984 conference at s.o.A.S. on the war in Africa; the conference ultimately led to the volume Africa and the Second World War, a special issue of the Journal of African History, and a series of individual papers. Some years earlier, a conference convened by U.N.E.S.C.o. in Libya collected pioneering regional surveys of the war in Africa, while two essays by Crowder surveyed the war in West Africa specifically. ${ }^{1}$ This concentration of scholarly activity in the 1970s and 80 s was also complemented by an expansion in historical scholarship produced in African universities; our understanding of the military history of Nigeria has been enlarged by the studies of Olusanya, Ukpabi, and Ubah. ${ }^{2}$ During the 2o1os, a series of major works emerged on Anglophone Africa during the war, including Killingray's Fighting for Britain and Byfield, Parsons, Brown, and Sikainga's edited collection Africa and World War 1 II. $^{3}$ These latter two works represent an expansion on the priorities in the earlier surveys of the subject; economic, labour, gender, African American, and military history emerge from their pages; yet both contributions of the 2010 seflected a divergence in approaches to the war in West Africa. While research on the economic and social impact of the war in West Africa is relatively developed, particularly in relation to certain regions such as Ghana and Nigeria, the military history of the conflict has often lagged behind; the civilian and military histories of the war are closely related, as many groups of civilians, such as clerks, technicians, or the wives of soldiers, found themselves suddenly bound up in daily interactions with the colonial military, or even seconded into its employment. ${ }^{4}$

This special issue includes essays on both military and civilian dimensions of western Africa during World War II; in particular, it seeks to show how West African actors played a major role in the military history of the war, in terms of military institutions and defence projects. Our focus is on Anglophone West Africa, especially the Gold Coast and Nigeria, with lesser coverage of the interesting cases of the Gambia and Sierra Leone. We will not consider Francophone or Lusophone West Africa, nor will we examine Liberia, all topics that deserve full consideration elsewhere. Concerning Anglophone West Africa, several of the 'lacunae' identified by Crowder during the 198 os continue to bedevil the military historiography of the war. Critically, the 'recruitment of

1 Crowder 1973; Crowder 1984, 1; Killingray and Rathbone 1982, 1; Mazrui 1982, 13; Roger Louis 1986, Gadsden 1986; Smyth 1984.

2 Ukpabi 1987; Olusanya 1968; Olusanya 1973, Ubah 1998.

3 Byfield 2015.

4 Dumett 1985, 381; Falola 1989, 73; Falola 1992, 412; Chuku 2010. 
soldiers and pioneers,' has benefited from some regional studies, yet remains unexplored in many regions of individual colonies, or in any systematic and comparative study; as we will see, the issue is controversial because it shows the extent of British-instigated coercion in the conscription and involuntary recruitment of soldiers, army labourers, and clerks. ${ }^{5}$ Similarly, Crowder's argument that 'local studies' represent a priority for the historiography of the war in West Africa might be reiterated today, although we are now largely unable to share his hope that 'survivors, military and civilian, are still alive and can be interviewed ...' ${ }^{6}$ While some veterans have been interviewed in the 2000 , the situation contrasts with that in 1980 when Holbrook drew on a sample of 340 ex-servicemen in Ghana; Israel (then Manns) and Holbrook deposited taped interviews with veterans in the libraries of John Hopkins University and Bryn Mawr College, respectively. ${ }^{7}$ In other cases, the field has moved on considerably; trans-regional studies have considerable potential, as West African troops moved between their home colonies and North Africa, Asia, and the Middle East; the cultural contact facilitated by these journeys raises wider questions about the contact between colonial African subjects, Indians, and Arabs. Several qualifications must be added to these lacunae, and the priorities that they represent, but these will wait until the conclusion of the present survey.

The papers in this issue examine only a slender minority of possible themes; their focus is disproportionately weighted towards the history of Nigeria. Gennaro explores the history of sport within wartime Nigeria, showing how sporting activities 'allowed Nigerians to contest colonialism's unequal social state.' Coates examines civil defence in Lagos, revealing how the colonial government and local African commentators clashed over the implementation of Air Raid Protection measures. ${ }^{9}$ Turning to the immediate post-war years, Mordi assesses demobilisation, highlighting the disconnect between colonial government resettlement policies, and the plight of veterans in rural areas and small towns. ${ }^{10}$ Focusing on Osun Division in southwestern Nigeria, Ajayi shows how local residents make financial, manpower, and material contributions to the war effort.1

\footnotetext{
$5 \quad$ Crowder $1985,288$.

$6 \quad$ Crowder 1985, 288.

$7 \quad$ Holbrook 1982, 155; Killingray David. The Colonial Army in the Gold Coast: Official Policy and Local Response, 1890-1947, Unpublished PhD Thesis, School of Oriental and African Studies, 1982, 415 .

8 Gennaro 2020, 4.

9 Coates 2020.

10 Mordi 2020D.

11 Ajayi 2000.
} 
Soldiers returned from the war, Olusanya argued, 'with new ideas, wider experiences and broader horizons,' these new experiences, he claimed, ensured that soldiers were 'not likely to take passively some of the practices which ... they had endured ...'12 The notion of soldiers returning from Asia with powerful new ideas has found a more recent restatement in the fictional character of Sergeant Bombay, the focus of Rotimi Babatunde's short-story Bombay's Republic; for Bombay, the war 'spawned possibility in his universe like body bags on the Burma front.'13 The overall picture in both accounts stresses the impact of military service, but not its detailed progression; into which constituent stages should we divide the war? ${ }^{14}$ We will divide the historiography of wartime West Africa into a series of similar chronologically sequential foci (recruitment, combat experience, and veterans' affairs), with the additional departure point of civil defence and internal security within British West Africa. This article will both provide an overview of World War Two in West Africa, and survey existing concentrations within the historiography of the field. Due to constraints of space we will only consider printed sources, and not the many war memoirs held in manuscript form within archives.

\section{Civil Defence and Internal Security in British West Africa}

West Africa remained almost entirely free of formal armed conflict, but until 1943 Anglophone colonies feared an Axis attack mounted from Vichy territory, or across the Sahara. This in turn provoked a pioneering program of civil defence measures, including the construction of air raid shelters, and the fortification of the region's major ports. The participation of Africans within Allied plans to fortify and protect West Africa has received little attention. While generally free from conflict, the war in West Africa was not always 'cold'; Special Operations Executive (s.o.E.) raids at Dakar on 23rd September 1940, and Fernando Po in January 1942, provide two famous exceptions. The failure of the British s.o.E.'s Dakar raid on 23rd September 1940, after initial plans had been indiscreetly circulated among Free French interests in London, contrasted with the 1942 attack on the port of Santa Isabel by two tugs sailing from Lagos, with 3

\footnotetext{
12 Olusanya 1973, 97.

13 Babatunde 2012, 33 .

14 Killingray 2010.
} 
Axis merchant vessels being towed back to Nigeria, including the 8,ooo tonne Italian liner the Duchessa d'Aosta, to the considerable embarrassment of the supposedly neutral Francoist regime in Spanish Guinea. ${ }^{15}$ Special Intelligence Services (s.I.s.) and S.O.E. operations in West Africa were largely focused on counter espionage and sabotage against German and Vichy interests. The role of wartime intelligence in West Africa has been most extensively researched on the Gold Coast, where s.o.E.'s Franck Mission, later the Political and Economic Research Office (P.E.R.O.) was established in Accra from January 1941, with the twin aims of 'coordinat[ing] propaganda' against Vichyite A.O.F., and 'undertak[ing] subversive activities. ${ }^{16}$ The British had no monopoly of intelligence work in Accra; the Free French operated the Service de Liaison d'Informations Centre Afrique (s.L.I.C.A.), while the Office of the Coordinator of Information (the forerunner to the American o.s.s.) sent Africanist anthropologists J.S. Harris and W. Bascom to collect intelligence. ${ }^{17}$ A key s.o.E. success on the Gold Coast was securing the movement of the Gyaman people across the border from the Ivory Coast into the Gold Coast. ${ }^{18}$ The s.o.E. network in West Africa appears to have relied to some extent on African informants, as in the case of the Gyaman, as did Allied military intelligence gathering in the region; this African assistance remains largely uncharted. ${ }^{19}$

From June 1940, the security of Britain's West African colonies looked newly precarious. The Gold Coast and Nigeria were vulnerable to land attack in three directions, while Lagos was situated mere miles from the border with Vichycontrolled Dahomey. ${ }^{20}$ Officials feared an Italo-German air attack originating from Tripolitania and targeting the Sahelian regions of Nigeria or the Gold Coast; in such an eventuality the British envisaged significant retreat. ${ }^{21}$ The Sahara did not constitute a definitive barrier to land invasion; Le Clerc's march from Lake Chad to join the Eight Army in North Africa had proved that transSaharan troop movements could be achieved ${ }^{22}$ Seaborne invasion represented a further threat; while much of the region's coastline was hostile to invasion due to mangrove swamps and treacherous surf and currents, there were vulnerable

\footnotetext{
15 Lett 2012; Jackson 2006, 216; Jeffrey 2011, 479-48o.

16 Lawler 1997, 54.

17 Lawler 1997, 54.

18 Jackson 2006, 226; N. Lawler 1997, 54.

19 Lett 2012; Jackson 20o6, 226; Jeffery 2011, 348-349.

$20 \quad$ Haywood and Clarke 1964, 363.

21 Haywood and Clarke 1964, 370.

22 Jennings 2015.
} 
areas near to Freetown and Takoradi. ${ }^{23}$ Axis naval power was concentrated at Dakar, with its naval base where, from September 1940, 3 heavy cruisers and destroyers arrived from Toulon; the port remained a Vichyite stronghold, but experienced economic isolation during the war. ${ }^{24}$

A.O.F. attitudes to Britain changed considerably between 1940 and 1942; the vicissitudes of French opinion had considerable significance for military and government planners in British territories. Wendell has shown how the Gold Coast expended significant energy broadcasting propaganda to French territories; including $13 / 4$ hours of Radio Accra's 4 1/4 hours of daily air-time. ${ }^{25}$ Despite rumours that Togo residents attended a hotel in Lomé to listen to B.B.C. broadcasts, it is unknown how effective these efforts were, and the French authorities destroyed radio sets and blocked B.B.c. transmissions. Attitudes, particular among French colonists, turned decisively against Britain after the destruction of Vichy's fleet at Oran in September 1940; the defeat was examined in graphic and exaggerated detail in Vichy propaganda, with one official Admiral Laborde claiming to have watched as British planes fired on lifeboats. ${ }^{26}$ The Ivory Coast authorities used the Bulletin Hebdomodaire and La Côte d'Ivoire, as well as the Journel Officiel to denounce Britain. ${ }^{27}$ Africans on the Gold Coast were aware of the new hostility towards Anglophone Africa in French territories, and had heard reports that Ghanaians were being rounded up on the neighbouring Ivory Coast. ${ }^{28}$ Yet it remains unclear how far these Vichy propaganda efforts influenced Africans inside the A.o.F.; even among French officials there remained some Gaullists, such as the Administrateur Supérieure of the Upper Ivory Coast, Ernest Louveau, who was later jailed at Dakar. ${ }^{29}$

Although seemingly arcane, an appreciation of the British military command infrastructure in the region is vital to any understanding of Africans' role in the war effort, as well as the broader social context of the war. Treatment of the institutional history of the R.W.A.F.F. has largely survived unchanged since Haywood and Clarke's account in the 196os; historians have tended to

\footnotetext{
23 Haywood and Clarke 1964, 363.

24 Haywood and Clarke 1964, 363; Hidalgo and Wélé 2018, 188, 192.

25 W. Holbrook, The Impact of the Second World War on the Gold Coast: 1939-1945, Unpublished PhD Thesis, Princeton University, 1978, 6o.

26 Ibid., 68.

27 Ibid., 67; Yao 1993, 564-566.

28 W. Holbrook, The Impact of the Second World War on the Gold Coast: 1939-1945, Unpublished PhD Thesis, Princeton University, 1978., 73.

29 Ibid., 71.
} 
eschew the study of the Force's central organisation and the functioning of West Africa Command. This is unfortunate because the Force underwent major changes during the war years; in July 1940 Lieutenant-General Giffard became head of the General Office Commanding West Africa, establishing a headquarters at Achimota College near Accra. ${ }^{30}$ Achimota played a major role in decisions affecting African civilians and troops across West Africa, as well as overseas. Although Giffard's initial priorities focused on the defence of Freetown and the Gambia, he presided over a major internal reorganisation of the R.W.A.F.F., installing an Area Commander for each territory, while initiating medical, transport, ordnance and supply services that became key sources of employment for many Africans. From April 1942, West Africa Command oversaw all military activities in the region. It should not be imagined that these organisations were omnipotent monoliths, and teething problems, particularly with regard to communications, plagued the nascent headquarters; slow postal services delayed communication with the United Kingdom, while the poor communications infrastructure inside West Africa early in the war constituted a major barrier. ${ }^{31}$

For the first time the British Army focused on the largescale recruitment and training African personnel in clerical and technical roles. Early training efforts faced shortages of matériel as well as language problems, but significant changes were made in the provision of weapons training, and preparation for fighting in different geographical environments. ${ }^{32}$ Dedicated infantry training centres were established for engineer and signal unit recruits, building on the army's recruitment of Yoruba signals clerks during the preceding decade. ${ }^{33}$ Women played a significant role in areas such as the new School of Cookery, established by the R.W.A.F.F. to cope with the considerable expansion in demand for military chefs, and run by a local market woman who became a well-known figure on the Gold Coast. ${ }^{34}$ Africans were barred from becoming officers until after the war creating clear racial discrimination within the military hierarchy; exceptions included the Achomita college graduate Seth Anthony, commissioned in 1942, and a number of other Africans who began preparing for commissions during the war. The shortage of British officers necessitated the use of white officers from Poland, South Africa, and Rhode-

$30 \quad$ Haywood and Clarke 1964, 364; Headrick 1978, 5 o3.

$31 \quad$ Haywood and Clarke 1964, 366, 368; Amenumey 20o8, 199; Agbodeka 1992, 119.

32 Haywood and Clarke 1964, 365 .

33 Haywood and Clarke 1964, 366; Stapleton 2019A, 17-24.

34 Haywood and Clarke 1964, 368. 
sia; between September 1941 and July 1943, some 273 Polish officers served in the R.W.A.F.F. ${ }^{35}$

The region served as a major shipping hub and carried considerable strategic importance for Britain because of its naval bases; Lagos and Freetown played a key role. Studies of wartime shipping, and of transport more generally, tend to be diffused between areas such as maritime, transport, and imperial history. Freetown's harbour could accommodate 250 ocean-going vessels, and in a single day during 1941 held 5 o vessels. ${ }^{36}$ Convoys bound for Europe formed in the port. ${ }^{37}$ By 1944, the 3 jetties forming Government Wharf handled about 66 tons a day of supplies, in November 1942, there were 80,00o tons of oil tanked on shore, ${ }^{38}$ while some 7,000 labourers were used to construct a naval base at nearby Kissy. ${ }^{39}$ Militarised by the United Kingdom in 1939, the port was defended by air from Waterloo aerodrome, 15 miles to the north, and, from 1942, boasted a United States military presence. The rapidly growing population of wartime Freetown led to conflicts between African and British servicemen, as well as growing crime rates in camps and billeted accommodation. ${ }^{40}$ In the Gambia, Bathurst became a naval centre supplying anti-submarine patrols and protecting convoy shipping in the mid-Atlantic; the British Overseas Airways Corporation used the town as a stop on its flying boat route between the United Kingdom and Lagos, while the colony was also a staging point on the bomber air route from Asia to the Americas ${ }^{41}$ On the Gold Coast, the interwar port at Takoradi played a pivotal role in receiving aircraft shipments for assembly and onward transit to the Middle East via the 'Takoradi route,' including intermediate stops at Lagos, Kano, Maiduguri, El Geineins, El Fasher, Khartoum, and Cairo. ${ }^{42}$ A major U.s. airforce base was established at Accra, with 200 to 300 planes stopping daily by $1942-1943{ }^{43}$

Lagos lacked Freetown's centrality for convoy traffic, but nonetheless constituted a major naval and mercantile hub. Like Takoradi, there are few accounts of the docks in Lagos during the war itself, although the conflict often plays a

\footnotetext{
35 Steward 2012, 69-71; Killingray 2010, 85-86; Jesman, 1965, 413-414; Healy 1999, 277.

36 Jackson 2018, 50; Killingray 2010, 29.

37 Howard 2015, 183.

38 Jackson 2018, 5 o.

39 Ibid.

40 Jackson 2018, 52; Stewart 2017, 10.

41 Jackson 2018, 54.

42 Haywood and Clarke 1964, 363; Stanley 1994, 459; Ray 1975, 340.

43 W. Holbrook, The Impact of the Second World War on the Gold Coast: 1939-1945, Unpublished PhD Thesis, Princeton University, 1978, 8o.
} 
background role in the historiography of Nigerian seafaring. ${ }^{44}$ Killingray provides several case studies; James Adewale departed for Dakar and then England as a merchant seaman, before working on vessels carrying war supplies to Normandy ${ }^{45}$ Perhaps because of the geographical range implicated in individual African mercantile careers, little is currently known about the wartime trajectories of a large sample of West African merchant seamen; the careers of men working through Liverpool, especially with Elder Dempster are better understood than the role of Nigeria merchant seamen in trans-Atlantic convoy shipping. Workers taken on at Lagos 'came from a wide range of ethnic groups spanning southern Nigeria' and were accorded the lowest rank on a four-tiered pay scale at the key shipping line Elder Dempster; this racialised inequality was challenged by some wartime African seamen in a strike in the latter port aimed at obtaining higher wages. ${ }^{46}$ The war played a significant role in the organisation of maritime labour; as Schler has shown, men recruited at Lagos founded the West African Union of Seamen in 1942. ${ }^{47}$ Integral aspects of Lagos's wartime maritime history remain poorly documented, including the experiences of Nigerian passengers of wartime passenger vessels, African interactions with Royal Naval personnel, and the role of coastal shipping during these years. Departing Lagos, those crossing the Gulf of Guinea soon found that danger was close at hand; as Coates argues in this issue, vessels faced threats from U-Boat patrols and mines placed at the port's approaches. In 1941, the dredger Robert Hughes was sunk by hostile explosives while entering Lagos. ${ }^{48}$ While the military trained some Sierra Leoneans to watch for submarines off the coast, African travellers were well aware of the lethal U-Boat threat, but their perceptions of submarines have received little research comparable to pioneering work on the cultural representations of aircraft and motor cars. This special menace soon impresses itself upon the reader of Fadoyebo's account of his return voyage from Sierra Leone to Lagos. ${ }^{49}$

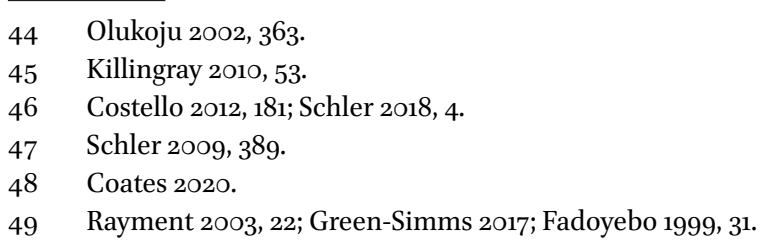


Identified by Crowder as a major gap in the literature, recruitment has attracted only a small number of case studies..$^{50}$ The subject is critical for several reasons; studies of recruitment practices may shed light on the nature and extent of coercion and offer clues about the social impact of military service. In any case recruitment, and particularly conscription, remains of considerable interest in the popular memory of World War Two in West Africa. This question of conscription remains key; several historians have argued that African military service was fundamentally voluntary, or that, where coercion existed, it was most immediately initiated by African actors, especially chiefs. ${ }^{51}$ We will see numerous instances of coercion, ranging from quotas to kidnapping. As in many other areas of wartime historiography in West Africa, a distinction must be made between the combatants and non-combatants. In the latter case, there is clear evidence that British colonial governments were willing to use conscription for military clerks as they became increasingly hard-pressed to recruit educated Africans. In order to avoid conceptualising recruitment in too general a manner, we must divide it into three areas: 'coercive' recruitment, for example by quota, conscription and compulsory secondment, and apparently 'voluntary' enlistment. ${ }^{52}$ The recruitment objectives of the R.W.A.F.F. differed at distinct stages in the war; Killingray delineates three distinct periods, the initial expansion of the Gold Coast Regiment in 1939-1940, the response to the perceived threat from Vichy A.O.F. in 1941/2, and manpower recruitment for Asia in 1943/4. Between October 1941 and 2, the G.C.R. doubled to 25,000, reaching 45,500 within a further fourteen months. ${ }^{53}$

Quotas given by the British to local chiefs played a key role in combatant recruitment. Even though formal combatant conscription was resisted by the Colonial Office from 1939 onwards as 'a costly and inefficient way to obtain reliable men in wartime,' this did not prevent British officials from pressurising local chiefs, who had to try desperately to meet their demands in order to stay in power. ${ }^{54}$ This quota system 'provided a means of conscription' with 'appalling' consequences for the individuals concerned as 'pressure was put on chiefs to provide their quota ... ${ }^{55}$ There were ample incentives; in the Northern Territo-

\footnotetext{
$50 \quad$ Crowder 1985; Ubah 1998; Iwe 1993; Mordi 2020C.

$5^{1}$ Crowder 1968, 150-151; Killlingray 2010, 44.

52 Abayomi and Oluwafunminiyi 2019, 15.

53 Killingray $1982,84$.

54 Killingray 2010, 44.

55 Killingray 2010, 46.
} 
ries of the Gold Coast, chiefs had been paid regular salaries since 1936 and this relationship ensured that 'military recruitment ... fitted neatly into the existing structural hierarchy' of colonial rule. ${ }^{56}$ It was not only commoners who were at risk of quota-based recruitment; Holbrook recorded instances where the sons of royal families were pressed into military service to further the careers of their chiefly fathers. ${ }^{57}$ Quota-recruitment may have played out at a local level, but it was an integral part of British military recruitment in West Africa.

Conscription and forced labour were particularly prominent in the case of non-combatant roles that required literate men who might not freely choose to join the military. The mechanisms for compulsory secondment were established in wartime legislation such as the respective Defence Regulations of each colony, and the Gold Coast's Compulsory Service Bill. Forced labour is better known in civilian cases such as on the Jos tin mines, but the British also used military conscription sporadically to target vagrants, convicts, and educated adolescents; the conscription of eight of the supposed ringleaders of the March 1944 King's College Strike is only the best known case. ${ }^{58}$ In early 1943, some 400 Bathurst 'corner boys' were rounded up by night and sent to a local army camp, and in Accra one man recalled being snatched from the street by soldiers in 1942; in Sierra Leone those arrested for illicit mining were sent to the army, and the courts offered defendants a choice between prison and military service. ${ }^{59}$ Oral testimonies in Ghana recalled British soldiers kidnapping young males, and driving them to military camps:

an army lorry's visit to a town became a dreaded occurrence in some areas, often leading to the flight of fearful young males. ${ }^{60}$

Felix Owusu-Ansah's autobiography Abongo Boy included an account of British soldiers capturing a young man from the Kumasi streets early in the war. ${ }^{61}$

Despite substantial coercive resources, including formal conscription, British officials were forced to convince Africans to voluntarily enlist; they visited local communities, mounting sports displays, drilling exercises, and

$5^{6}$ W. Holbrook, The Impact of the Second World War on the Gold Coast: 1939-1945, Unpublished PhD Thesis, Princeton University, 1978, 167.

57 Ibid., 161.

58 Killingray 2010, 48; W. Holbrook, The Impact of the Second World War on the Gold Coast: 1939-1945, Unpublished PhD Thesis, Princeton University, 1978, 167; Killingray 2010, 50; Olusanya 1973; Thomas 1973, 79 .

59 Killingray 2010, $5^{\circ}$.

6o Holbrook 1982, 162 .

61 Holbrook 1982, 162. 
parades, while also making recourse to specially conceived propaganda. ${ }^{62}$ From 1941, mobile cinema units urged locals to join the army, while from January of the preceding year press adverts appealed for literate recruits. ${ }^{63}$ Radio programs recounted the exploits of the R.W.A.F.F. in East Africa, and 'specific acts of valor by Gold Coast soldiers' were covered in detail. ${ }^{64}$ Prominent women such as Mabel Dove Danquah and Ruby Papafio, journalist and educator respectively, gave broadcast talks urging support for the British, while Prempeh II, the Asantehene, spoke in favour of the Allied war effort. ${ }^{65}$ These efforts were complimented by recruitment bands whose songs sought to 'attract men to the colours,' sometimes using linguistic strategies such as a pun on the Akan word barima (warrior/ brave man) and the similar-sounding 'Burma.'66 At Abeokuta, in southwestern Nigeria, a six-week tour of soldiers and tradesmen gave demonstrations, and performed physical drills and training in the hope of attracting recruits; while in the North, rulers such as the Emir of Kano, Abdullahi Bayero, played an important role in recruitment efforts, and recruiting durbars assembled chiefs and military representatives together in order to urge men to enlist. ${ }^{67}$

Intimately related to recruitment was the question of remuneration; for certain categories of recruit, pay was a motivational factor, but the dramatic racialised disparities in pay rates between British and African personnel revealed blatant racial discrimination. The nature and significance of military pay rates for Africans continues to generate controversy; despite its importance, there are very few studies of West African pay and savings in the R.W.A.F.F., and the subject typically emerges at the margins of studies with other foci. Private African combatants were paid one shilling a day in the West African Forces, compared to the two shillings daily received by British privates. ${ }^{68}$ Additional allowances were introduced during the war; from 1940, a system of marriage and overseas allowances came into operations, as well as proficiency and trade payments, while from November 1942, separation allowances, sometimes known as 'allotments,' were paid to soldiers' wives. ${ }^{69}$

\footnotetext{
62 Mordi 2020A; Mordi 2017; Ross 1983.

63 Killingray 1982, 92; Ibhawoh 2007, 1; C. Thomas, Colonial Government Propaganda and Public Relations and the Administration in Nigeria, 1939-1951, Unpublished PhD Thesis, Cambridge University, 1986, 57; Holbrook 1985, 347.

64 Holbrook 1985, 354 .

65 Holbrook 1985, 354.

66 Killingray $2010,47$.

67 Killingray 2010; Byfield 2015B; Byfield 2007, 77.

68 Hamilton 2001, 31.

69 Killingray David. The Colonial Army in the Gold Coast: Official Policy and Local Response,
} 
Soldiers fighting in Burma later in the war received an expatriation allowance of 10 shillings monthly. ${ }^{70}$ Partly with an eye to demobilisation, the military authorities encouraged soldiers to save some of their pay; until December 1943, deferred pay was withheld by the paymaster and accrued no interest; from that month the R.W.A.F.F. adopted an Army Savings Scheme, with the aim of ensuring that soldiers left the military with savings. ${ }^{71}$ Post Office savings accounts were popular with a minority of servicemen; by 1945, 3,700 men from the Gold Coast had saved $£ 158,523$, or around $£ 40$ each, in these accounts. ${ }^{72}$ While some historians have argued that the real value of African soldiers' pay in the African economies of the time was relatively high, it remains clearly apparent that pay was awarded discriminatively on a racial basis. ${ }^{73}$ Furthermore, African soldiers 'became keenly aware' that they were paid substantially less than British troops, and this combined with the more generalized experience of racism in military service to provoke African anger. ${ }^{74}$

However, in the matter of remuneration it is again critically important to differentiate between combatants and military technicians and clerks: the two groups had distinct pay scales. Non-combatants were sharply differentiated in terms of skill level and pay; for educated or skilled non-combatants, the pay represented 'brighter pay prospects' in comparison to civilian occupations in the wartime economy. From June 1942, new and higher rates of pay were introduced to attract clerical workers into military service. As Mordi has show, for a third-class clerk employed by the provincial administration in Nigeria on a salary of $£ 48$ per annum, secondment to the Army brought in $£_{72}$ yearly in 1942; the highest categories of clerks in military employment could expect to earn $£ 76$ and $£ 85$ per annum..$^{75}$ Despite these higher pay rates, the treatment of clerks could be draconian; civil servants and other workers were routinely seconded to the army as civilian staff under the Defence Regulations of 1940; in 1942 the Nigerian Railway at Ebute Metta had released 81 staff to the army. ${ }^{76}$ Finally, Army Pay Offices themselves constitute a largely unexamined subject; the R.W.A.F.F.'s Pay Branch employed a significant number of African staff,

1890-1947, Unpublished PhD Thesis, School of Oriental and African Studies, 1982, 218; Killingray 2010, 95.

70 W. Holbrook, The Impact of the Second World War on the Gold Coast: 1939-1945, Unpublished PhD Thesis, Princeton University, 1978, 215.

71 Killingray 2010, 95 .

72 Killingray 2010, 95 .

73 Hamilton 2001, 31.

74 Killingray 2010, 95 .

75 Mordi 2019A, 849 .

76 Mordi 2019A, $85^{2}$. 
with the Force's Paymaster and Financial Adviser receiving little immediate institutional support. ${ }^{77}$

Recent research has shown that some Africans enthusiastically supported the war effort, at least in the first months of the conflict; this may be linked to the relatively widespread awareness of the racial politics of Nazism, and ongoing opposition to Italian fascism. ${ }^{78}$ Many Africans, including in rural areas, were aware of the threat that Nazi expansionism posed to sub-Saharan Africa; the work of Clarke and Mordi has shown how a cross-section of wartime society was well aware of wartime events in Europe. Although Clarke's study of wartime propaganda has been criticised for being overly general, it nonetheless contains a wealth of material absent in other works. ${ }^{79}$ As Mordi has recently demonstrated, some Nigerians eagerly supported the intellectual objectives of the war effort, such as anti-fascism, while others were attracted by the perceived career progression offered by military trade and technical roles. Mordi suggests that 'Nigerians' enthusiasm to fight for Britain' played a key role, sometimes gestating into 'despondency and [a feeling of] doomsday' when their commitment was rebuffed by the colonial government. ${ }^{80}$ Major philanthropic fundraising drives were undertaken for the Nigeria War Relief, Win the War, Joint Relief, and Polish Relief Funds; Kano raised £10,270 in 1942, of which $£_{5}$, 0 oo was used to buy a Spitfire bearing the municipal name, while in August 1943, a Mosquito Bomber named Nigeria was purchased with $£_{20}$, ooo from the Win the War Fund. ${ }^{81}$ Significantly, support for the war effort extended beyond elites; as Clarke has shown, many Nigerians were aware of the existence of figures such as Hitler, who became the subject of admonitory tales to children, while the battle of Alamein was staged in some local market squares; 'many people in rural areas,' Clarke concludes, 'knew a great deal more about the war' than historians assumed. ${ }^{82}$ Similarly Africans played key roles, as Ibhawoh argues, 'in the production and dissemination of war propaganda,' using 'war rhetoric to promote their long-term goals.' ${ }^{\text {' } 3}$

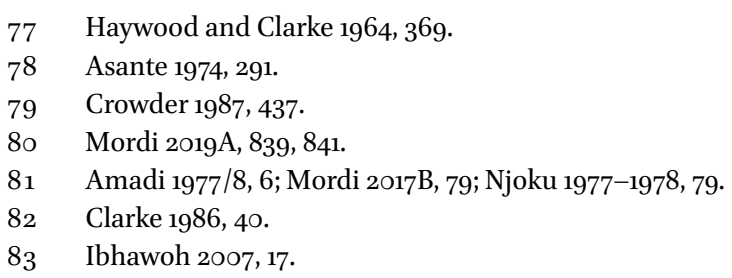


Anglophone West African troops fought in East Africa, Asia, and the Middle East; accounts of these engagements are often relegated to the histories of specific divisions; to an extent this is indicative of Thomas and Doron's contention that 'the study of battles and warfare itself' have received less attention than the history of the social consequences of war. ${ }^{84}$ In any case, the significance of Africans' overseas military service extends beyond combat, and encompasses soldiers' leisure, cultural, religious, and medical experience. ${ }^{85}$ Military service in Asia and the Middle East brought soldiers into contact with cultures and peoples far from their home colonies; it gave rise to unprecedented moments of contact between continents, such as the 'cafés of Cairo,' which, as Sikainga argues, became 'important sites of interaction among African, European, and American servicemen.' 86

Within all of this, the voices of individual soldiers have not been heard and there is sometimes a tendency to reproduce an anonymous category of 'African soldiers' with little differentiation or nuance. This has recently been challenged by historians who have questioning the 'treat[ment of] ... African soldiers ... with anonymity and condescension,' and the perpetuation of 'the anonymity of soldiers from Nigeria who fought in Burma. ${ }^{187}$ This marginalisation of African voices has been attributed to diverse motivations, ranging from interpretative priorities that 'tend ... to denigrate African contributions,' to the limitations of colonial archive sources. ${ }^{88}$ Existing African accounts from the war have attracted less scholarship than has been the case in studies of First World War West Africa. ${ }^{89}$

Best known among African accounts of the Asian campaign is A Stroke of Unbelievable Luck, Nigerian Isaac Fadoyebo's memoir of his experience as a medical orderly in Burma. Paradoxically, although his case has attracted a slim body of academic research, Fadoyebo has been the subject of a popular nonfiction work and a documentary film. ${ }^{90}$ Unbelievable Luck recounts Fadoyebo's experiences of combat, reminding us of the degree to which supposed noncombatants were plunged into active conflict. It hinges around Fadoyebo's

\footnotetext{
84 Roy 2010; Barkawi 2017.

85 Hamilton 2001; Stewart, 2016; Doron and Thomas 2019.

86 Sikainga $2015,506$.

87 Mordi 2019A, 839; Morrow 2010, 22; Igbino 2018, 76 .

88 Mordi 2019A, 839 .

89 Newell 2008; Mullen and Newell 2008.

$90 \quad$ Fadoyebo 1999; Coates 2016; Aderinto 2014; Killingray 1997, 93; Phillips 2014.
} 
experience of being sheltered by a Burmese Muslim farming family for just over ten months, from March to December $1944 .{ }^{91} \mathrm{~A}$ further example is J.O. Ariyo's Yoruba war memoir Oju Mi Ri Ni India ('What I Saw in India'), which recounts the Asian war as well as Ariyo's experiences of South Asia; 'There was a Soldier' presents a biography of northern Nigerian soldier Hama Kim's career based on a veteran's oral testimony and partly focused on World War Two. ${ }^{92}$ While Fadoyebo and Ariyo wrote at a chronological remove from the war, newspapers such as the Ashanti Pioneer, West African Pilot, and Nigerian Daily Times printed contemporary letters from soldiers serving in Asia, as well as producing a considerable body of commentary on the war. Access remains a critical issue in the case of newspaper research on World War Two West Africa; the Pilot and Times of the war years exist in extensive microfilm and digital holdings often reliant on costly institutional access packages, while comprehensive holdings of the Pioneer and African language newspapers are largely only available within African archives. ${ }^{93}$ Soldiers letters to families, District Officers, Nigerian politicians, or religious leaders, exist on a considerable scale in African archives and represent a largely unexamined source. ${ }^{94}$ The writings of contemporary African observers form a further body of material; the Hausa poet Sa'adu Zungur celebrated the participation of Nigerian troops in East Africa. ${ }^{95}$ 'The Nigerians' he recounted:

... cleaved through to the Somali corner without halting.

The Ethiopians drank freely in city, in encampment, and in village.

Their enemy was knocked out. Ethiopia's troubles were over. ${ }^{96}$

Beyond memoirs, journalism, and literature, a significant body of soldiers' songs exists; as well as photography of African troops preserved in military newspapers such as the R.W.A.F.F. News. ${ }^{97}$ The iconography of the R.W.A.F.F.

$91 \quad$ Fadoyebo 1999, 42.

92 Ariyo 1957; Graham 1985.

93 Mizobe 2012, 26.

94 Coates 2018A, 71; Korieh 2010; Korieh 2014; B. Alozie, 'A Privileged Communicative Space: Nigerian Soldiers' Petitions During the Two World Wars,' Unpublished Conference Paper presented at the Twelfth Annual Association for the Study of the Middle East and Africa Conference, Washington D.C., 31st October to 2nd November 2019, I am grateful to B. Alozie for sharing this paper with me.

95 Crowder 1984, 17; Abdulkadir 1974, 41.

96 Killingray 2010, 148.

97 Owen 2020; Coates 2018B, 200. 
also inspired appropriation and imitation; the 81st Division's logo of the tarantula was used by soldiers in tent thatching and even hairstyles. ${ }^{98}$

West African troops appeared in the pages of British newspapers, but they also became an object of fascination in the Japanese press. ${ }^{99}$ Mizobe has shown how the Tokyo newspaper Mainichi Shimbun (Tokyo Nichi Nichi) ran numerous stories about African troops during 1944; the word 'seia-gun' or 'West African troops' appeared on the newspaper's front page 8 times in that year, while, Mizobe argues, the articles themselves varied between criticising the treatment of Africans as 'victims of Western imperialism,' and asserting that African soldiers were 'helpless in the face' of Japanese attacks. ${ }^{100}$ The term Seia-gun appears to have designated West African soldiers specifically, despite the presence of East African troops in Burma. ${ }^{101}$ Descriptions of West Africans also appeared in Japanese officers' diaries. ${ }^{102}$

Despite the fact that the East African campaign is covered in official histories, British officers' memoirs, and theatre-specific studies, many aspects of the West African experience in East Africa remain obscure. ${ }^{103}$ The eventuality of a campaign in East Africa had been anticipated since the 1938 when the West African Expeditionary force began preparations; by the time Italy entered the war in June 1940, troops were already travelling towards the Cape. ${ }^{104}$ Upon arriving in East Africa that month, West Africans were organised into two formations; the 11 and 12th African Divisions. ${ }^{105}$ Many accounts of West Africans in East Africa are incorporated into either campaign histories, or more general accounts of the war in Africa; there are few dedicated accounts of West African soldiers' activities in East Africa aside from their combat record, such as their life in camps in the region, or their perception of Italians. ${ }^{106}$

The Burma campaign remains the best documented of West African wartime overseas operations; it is documented in divisional histories, Parsons' work on the K.A.R., and in comparative studies by South Asianists. ${ }^{107}$ Despite the relative abundance of primary and secondary sources, our understanding

98 Rayment 2003, 16.

99 Killingray 2016, Mizobe 2015.

100 Mizobe 2015, 174-175.

101 Mizobe 2015, 176.

102 Mizobe 2018, 1.

103 Bruce 2014, Bruce N.D.; Dower 1949; Kerslake 1997; Lanning 2013.

104 Killingray 1983.

105 Haywood and Clarke 1964, 331.

106 Stewart 2016; Killingray 2010; Stapleton 2013.

107 Roy 2010; Barkawi 2017; Parsons 1999; Parsons 2017; Rayment 2003. 
of the activities of West African troops in Burma varies by military formation. The 81st W.A. Division's combat record in Burma is explored in a relatively large body of work, ranging from British officers' memoirs, to a detailed historical study. ${ }^{108}$ Soldiers such as Fadoyebo served in the Division, as part of the 6th West African Brigade, and another formation, the 3rd West African Brigade, was seconded to form part of the Chindits special forces under Orde Wingate. ${ }^{109}$ Despite the density of material focusing on the Division's time in Burma, existing accounts tend to privilege a sequential narrative of battles and engagements, while substantive questions about combatants' perceptions of fighting, interaction with Burmese society, enemy soldiers, or engagement with medical, religious, or welfare services have been neglected. ${ }^{110}$

The 82nd Division's role in Burma has received less attention; arriving in July 1944, the Division fought during the 3rd Arakan Campaign, suffering the highest casualty rate among Britain's XV Corps at some 2,085 men, before spending a further year in South-East Asia in peacekeeping roles. ${ }^{111}$ Particularly heavy casualties were taken by the Division's 1st and 4th (Nigerian) Brigades during the February 1945 opening of routes into Kaw and Kyweguseik. In March, alongside Indian units, the 82nd Division helped capture Dalet Chaung and Tamandu. ${ }^{112}$ The Division's service record, not least its protracted stay in Burma after the conclusion of hostilities in August 1945, suggests that its history is likely to differ markedly from the better-known case of 81st Division, which spent months in India after the war.

In all of this, the 'rear echelon' units based in India, as well as African troops on the subcontinent, have been somewhat neglected. The notion of military cartographers or signals technicians sitting far from the conflict in central India does not fit with the image of West African 'Burma boys' deployed to the jungles of South-East Asia. Yet India-based units played a crucial role in supporting active troops, providing medical, logistical, and entertainment services. Concentrated in regions such as Jhansi, in modern-day Uttar Pradesh, and Bengal, the experience of West Africans in India differs markedly from that of combatant troops in Burma. An initial account of Africans in India appears in Killingray's survey Fighting for Britain, where the focus is on matters such as food and drink, entertainment facilities, and troop mutinies. ${ }^{113}$ More recent

\footnotetext{
108 Hamilton 2001.

109 Fadoyebo 1999; Stapleton 2013, 232.

110 Killingray.

111 Stapleton 2013, 233.

112 Staplteon 2013, 233.

113 Killingray 2010; Stapleton 2013.
} 
work has focused on soldiers' travels in India, and the role of photographic sources in documenting African life in Asia during the war. ${ }^{114}$

Not all West African troops served under the R.W.A.F.F.; some 16,472 West Africans served as military labourers in the Middle East as part of the Africa Auxiliary Pioneer Corps (A.A.P.C.). ${ }^{115}$ Formed in 1941, due to chronic need for labour by Middle East Command following the Allied defeat at Tobruk, the Corps already consisted of men from eastern and southern Africa. ${ }^{116}$ In West Africa, pioneers were recruited chiefly in Nigeria, particularly the Igbo, Ibibo, and Efik peoples, and Sierra Leone; once in the Middle East, the men worked constructing airfields, fuel dumps, runways, and other logistical tasks. Although functioning as labourers, many African who served in the Corps received firearms training and operated close to active combat. ${ }^{117}$ Service in the Middle East carried unique attractions for African troops, notably the proximity of Mecca and Jerusalem; the rest camp for African troops close to Jerusalem was particularly popular and contemporary photographs document soldiers' tours of the 'Holy City's' religious sites. ${ }^{118}$ One Nigerian soldier recalled celebrating Easter at Christ Church on Mount Zion; notable religious sites were laid out in the booklet Walks Around Jerusalem, aimed specifically at literate Africans. ${ }^{119}$ These overseas rest camps, including others near Cairo and Beirut, were soldiers' only chance of leave, and home leave was prohibited for Africans serving in Asia. ${ }^{120}$

African soldiers' overseas service provoked unrest; troops faced substantial discrimination in terms of pay, food rations, and the fact that they were subjected to degrading corporal punishment long banned for British soldiers. ${ }^{121}$ Mutiny, or the threat of it, has long constituted a key theme in accounts of African soldiers overseas during the war; Killingray's Fighting features a chapter dedicated to the subject. Troop rebellions, as Cole as shown, predated overseas military deployment; in January 1939, soldiers from the Sierra Leone Battalion took part in the 'Gunners' Mutiny,' angry at poor pay rates, 'lack of promotion prospects,' 'white officer arrogance,' and the military's refusal to issue soldiers with boots. Despite the threat of severe punishment, the mutineers

\footnotetext{
114 Coates, 2018B, 200; Coates 2018C,1.

115 Coates 2018D, 1; Killingray 1979, 433, fn. 65 .

116 Killingray 2010, 68.

117 Killingray 2010, 62.

118 Killingray 2010, 102.

119 Coates 2018D, 2.

120 Killingray 2010, 107; Killingray 2001, 440.

121 Killingray 1994, 201.
} 
succeeded in winning concessions from the R.W.A.F.F. ${ }^{122}$ In Asia, rebellions became increasingly common in 1945; Killingray's list of such risings include West African troop protests at Poona, Dhakka, and Karvetnagar. ${ }^{123}$ The rebellion at Karvetnagar in Madras Presidency raised the ultimately unrealised prospect of the British using Indian troops to supress African mutineers. ${ }^{124} \mathrm{~A}$ situation close to mutiny occurred as African soldiers returned home, on board the H.M.s. Ruys. ${ }^{125}$ As Killingray argues, 'it is surprising that serious unrest did not occur more frequently' given the material hardship and racial discrimination faced by African troops; the fate of those troops sentenced to jail terms for rebellion, such as some of those at Karvetnagar, remains unclear, as do the details of rebellions in Poona and onboard the Ruys. ${ }^{126}$

The fate of ex-servicemen in post-war West Africa has generated one of the longest standing debates in the historiography of World War Two in the region; demobilisation, by contrast, has received far less attention, and it is all too easy to assume that it simply formed a prelude to the government neglect of veterans. Research on ex-servicemen's careers necessarily occurs at a chronological remove from the end of the war itself, although veterans' lives and organisations have rarely been studied into the post-colonial period. ${ }^{127}$

Demobilisation represented an unprecedented movement of African manpower; by the end of the war, 28,500 Gold Coast soldiers were still overseas in Asia. ${ }^{128}$ While recruitment had occurred in several waves from the late 193 os onwards, demobilisation was concentrated into an 18 month period from August 1945; the vast majority of enlisted servicemen left the army at the war's end. ${ }^{129}$ Upon release, soldiers were entitled to gratuities, ranging from $£_{3}$ o for a Regimental Sergeant Major who had travelled outside Nigeria, to $£_{14}$ for a private who had only served inside the colony. ${ }^{130}$ This delay in shipping, stretching from August 1945 through to the following autumn has been ascribed to various

\footnotetext{
122 Cole 2014, 290; Cole 2013, 15.

123 Killingray 2010, 132-133.

124 Coates 2018C.

125 Killingray 2010, 133.

126 Killingray 2010, 137.

127 Israel 1992, 359; Coates 2017; Mordi 2020A.

128 Killingray $1982,94$.

129 Miners 1971, 243.

130 Miners 1971, 243.
} 
factors. Killingray has argued that shipping shortages remained a significant problem and that British troops were prioritised on available vessels, leaving frustrated Africans stuck in India; the military authorities stressed this paucity of suitable ships, but, as Jackson has demonstrated, many Africans and their British officers remained sceptical of this reasoning. ${ }^{131}$ As Mordi has shown, African servicemen 'occupied the bottom rung' on many officials' priorities when it came to planning demobilisation; the racialized disdain with which troops were treated in turn helped to 'lower ... the prestige and rating of Britain' in their eyes. ${ }^{132}$

The bureaucratic mechanisms of demobilisation may seem arcane, yet they were unprecedented in their ambition, and, as such, established an unobtainable precedent for the increasingly cash-strapped late colonial state. Legislation such as the Resettlement Act of 1945, and the Employment of ExServicemen's Ordinance formed an ambitious blueprint for government intervention in local economies to secure employment for returning soldiers by means of loans, quotas, and training; in Nigeria, a network of registration centres were established in provincial centres such as Kaduna, Ibadan and Enugu. ${ }^{133}$ As Parsons has argued in the case of Kenya, colonial governments had nominally greater obligations to disabled veterans; disabled men had access to rehabilitation, prosthetic limbs, and pensions. ${ }^{134}$

Ex-servicemen have recurrently been understood as either inherently politicised or, conversely, politically 'impotent'; the reality, as Mann has argued in the case of the A.O.F., lay between these two poles. ${ }^{135}$ It is necessary to differentiate between ex-servicemen in terms of economic background, geographical location, and physical or psychological injuries. Skilled clerks had an entirely different relationship to the post-war labour market than drivers or combatants. ${ }^{136}$ Without suggesting colony-wide political mobilisation, we must nonetheless take seriously individual veteran's local engagements in politics. Killingray provides a list of individual veterans' participation in Nigerian politics: J.M. Johnson, Federal Minister of Labour from 196o-1963, Zikist politician Heelas Chukwuma Ogokwe, several representatives of the Tiv Progressive Union, and the first Tiv paramount chief, or Tor Tiv, ex-serviceman Makeri Zakpe in $1947 \cdot{ }^{137}$

\footnotetext{
131 Killingray 2010; Jackson 2006.

132 Mordi 2O2OA, 24.

133 Mordi 2020C 3.

134 Parsons 2015, 13 O.

135 Olusanya 1973, 102; Killingray 1982B, 95; Mann 20o6, 108.

136 Mordi 2O20C.

137 Killingray 2010, 219.
} 
Veterans participated in the 1947 revolt against the Yoruba chief imposed at Makurdi, and played a role in the United Middle Belt Congress. In the legal profession, T.A.B. Oki became Lagos State Attorney, and Alhaji I.A.S. Adewale, Commissioner of Finance. ${ }^{138}$ Earlier scholarship records further examples that merit inclusion because they demonstrate the involvement of veterans in society that was still evident during the 1970s; Chief J.O. Olaniyonu of Inalende Ibadan, Chief Lawani Hassan Oluwo, also Omopupa of Mushin-a prominent transporter, Akinsilo the owner of Toyin Bakery, the stevedore S.B. Bakare of Ijesha Lodge Lagos, Banana Sambo, security officer at Amadu Bello University in the early 1970s, and Jirgin Mbula Numan, who served 'as a messenger in many offices' since leaving the Army.139 Individual ex-servicemen played an important role in the civic life of Nigerian towns into the Second Republic.

In the case of Ghana, the historiography ex-servicemen's associations is more developed, with such organisations having a longer history, dating back to the First World War. ${ }^{140}$ The February 1945 formation of the Gold Coast Legion was modelled on the British Legion. By mid-1948, the Legion had 205 European and 36,006 African members, while by 1950 it was estimated to have an African membership of 50,000.141 The Legion erected an ambitious series of memorial halls in Accra, Kumasi, Koforidua, and elsewhere, renovating the old soldiers' home in Kumasi, and building a settlement at Yendi. It provided free medical services for ex-servicemen, their wives and children under 12 years, as well as accommodation in some locations, and free legal aid. Veterans, however, were unconvinced by the legion, which, Killingray argues, 'failed to adequately answer ... the grievances of some ex-servicemen.142 Into the void stepped a reformed Ex-Servicemen's Union, reformed by B.E.A. Tamakloe in 1946, and claiming 6,650 members by 1948, mostly in Kumasi and the southern regions of the Gold Coast; the Union briefly published its own paper, Ex-Service, in 1947. It took a far more critical tone than the Legion and challenged what it alleged to be Government failures in the treatment of ex-servicemen; a February 1948 petition outlined 7 grievances, including demands for the release of 12 ex-servicemen from prison, increased pensions for disabled soldiers, rehabilitation funds, accelerated Africanization in the R.W.A.F.F., exemption from

\footnotetext{
138 Olomola 1976,54 .

139 Olomola 1976, 54.

140 Killingray, David. The Colonial Army in the Gold Coast: Official Policy and Local Response, 1890-1947, Unpublished PhD Thesis, School of Oriental and African Studies, 1982, 405.

141 Ibid., 408.

142 Ibid., 410.
} 
levies, greater official efforts to find jobs for veterans, and quicker payment of war credits. ${ }^{143}$ Despite this ambitious program, the Union, Killingray contends, was only representative of 'the economic grievances of certain ex-servicemen,' and was neither socially, nor geographically, representative. ${ }^{144}$ Political parties such as the United Gold Coast Convention increasingly sought to use veterans as 'raw material.' The well-known role of ex-servicemen in the 28th February 1948 march on Christiansborg Castle is illustrative of the point; it is unknown how many of the 2,00o strong crowd were ex-servicemen, and some veterans present only knew about the event at very short notice, itself indicative of their likely low participation in Union activities. ${ }^{145}$

Our understanding of ex-servicemen's impact on rural societies remains poor, as does the degree to which veterans' associations engaged in informal social organizations and clientelist forms of politics. Veterans' attempts to found businesses, successful or otherwise, await dedicated attention, at least in the case of Nigeria. We have a clearer grasp of the legislative foundation of government-sponsored organisations such as the Nigerian Ex-Servicemen's Welfare Association (N.E.W.A.), and their Nigerian-founded competitors during the 1940s. From 1946, the Association established a system of Regional and District Councils, including 34 of the latter in the Northern, 20 in the Western, and $3_{1}$ in the Eastern Regions; it despatched $£_{12,938}$ in funds in 1947, and $£ 13,988$ 10s $4 \mathrm{~d}$ in 1948 . ${ }^{146}$ The Association offered medical treatment to handicapped ex-servicemen, as well as spectacles and false teeth, while issuing loans for veterans to purchase tools or develop businesses. Olomola's pioneering work on the Association examined some of the financial awards it made to veterans; the Ekiti Ex-servicemen Building Association received a £200 loan, while veterans in Kontagora attended a market gardening course in Kano with the help of a $£ 10$ loan. Two men in Awka received a N.E.W.A. loan to purchase sewing machines, and establish a 'sewing institute.'147 The Association also supported veterans' clubs in Lagos, Kano, Ekiti, Aba, Pankshin, and Victoria, as well as other associations in Lagos, Ado-Ekiti, and Ondo. ${ }^{148}$ Despite these efforts, the Association's relationship with veterans remained aleatory; some ex-servicemen used its infrastructure for personal gain, while others shunned the N.E.W.A. as unrepresentative of their interests. In any case, significant

\footnotetext{
143 Ibid., 410-411.

144 Ibid.

145 Ibid., 414; Prah 2014; Prah 2016.

146 Olomola 1976, 5 o.

147 Ibid.

148 Olomola 1976, 51-52.
} 
financial retrenchment prompted the closure of 18 Association centres in the Northern Region in 1948, with most district offices closing across the Eastern and Western Regions. ${ }^{149}$

Beyond the N.E.W.A., more radical and African-led veterans' organisations existed in Nigeria, including the the Lagos Ex-Servicemen's Organisation, the National Union of Demobilized Servicemen, the Supreme Council of ExServicemen, and the Nigerian Federation of Ex-servicemen's Associations. Lagos proved an important centre of veteran militancy, particularly surrounding disabled ex-servicemen who garnered column inches in the African press following dramatic protests. ${ }^{150}$ Local studies are most developed in Eastern Nigeria, a region where, Nwaka contends, veterans were 'more cohesive and combative;' ex-servicemen organized revolts in the Aba area of Owerri Province, and in October 1950 in Umuahia. ${ }^{151}$ More recently, Mordi's account of the N.E.W.A. and its competitors has begun to unpick the career of regional ex-servicemen's movement leaders such as O.N. Egesi, President of the Nigerian Ex-Servicemen's Union, revealing the multiplicity of their motivations..$^{152}$ Veteran militancy did not always gain widespread public sympathy; ex-servicemen, Olomola contends, 'became the talk of people from all walks of life' in Nigeria during the later 1940s, where the public 'made up stories of the exsoldiers' predisposition to crime and social problems,' and local bands 'composed abusive songs about ... veterans.' ${ }^{153}$

\section{Conclusion}

Since 2000, West Africa's experience of World War Two has garnered significant popular interest; West Africans' contributions to the war have become the subject of documentaries, and popular books. Even as the conflict passes beyond the horizon of living memory, it seems that the region's role in the war has its own historical memory both in West Africa and in Britain. Admittedly still slim, this body of material includes several documentary films, such as Owen's series of interviews with veterans in central Nigeria, and Keazor's historical survey of the Nigerian contributions to the war, making extensive use of archive

\footnotetext{
149 Olomola 1976, 54.

150 Coates 2017.

151 Killingray 2010, 218; Nwaka 1987, 47, 54.

$15^{2}$ Mordi $2020 \mathrm{~B} 594$.

153 Olomola 1976, 54 .
} 
recordings of soldiers' songs. ${ }^{154}$ The life of Isaac Fadoyebo has been charted in Phillip's documentary film for Al Jazeera, as well as a non-fiction book. ${ }^{155}$ West African soldiers have taken central roles in fictional narratives by Bandele and Babatunde, while Preprah-Gyamfi has created an historical novel that also seeks to function as an educational resource. ${ }^{156}$

We have seen that the historiography of British West Africa during World War Two is complex and wide-ranging; that the field has expanded significantly from its inception during the 1970s. Research on the war faces new challenges; while the search for living veterans formed an important motivation for much research in the 1980s and 199os; it will soon become an impossibility. Despite this limitation, resources beyond the colonial archives, including newspapers and photography, present new opportunities for future research, as do the significant and largely unexplored body of African voices contained in petitions and other epistolary texts preserved within African archives. While we have seen that some long-standing questions in the historiography of the war have remained unanswered since Crowder's 1985 survey of the field, particularly recruitment and regional studies of the impact of military service, newer research questions continue to expand the field's scope. Religion, for instance, has been identified by Killingray as a key element within military service that remains largely unexplored; Stapleton has recently examined the military recruitment of imams and chaplains, showing how this 'important and dynamic aspect' of the R.W.A.F.F. and its predecessors led to a changing and specialised workforce of religious ministers within the army. ${ }^{157}$ Officers' perceptions of African religious affiliation, continuously changing, played a key role in driving the military's recruitment strategy during the war, particularly at a local level; imams represented relatively powerful intermediaries, presiding over Hausa language studies, and travelling to South Asia with their men. ${ }^{158}$

The history of gender has been examined in relative detail with regards to West African civilians during the war, but until recently there had been little work focusing on the military. ${ }^{159}$ Ray has examined prostitution in West African ports, and Korieh has brought a focus on wartime African masculinity explicitly to the fore; 'men's engagement in the war conferred new power and status,' with 'civilian male workers' also participating in distinctive forms

\footnotetext{
154 Owen 2020; Keazor 2019.

155 Phillips 2014.

156 Bandele-Thomas 2007; Babatunde 2012; Preprah-Gyamfi 2018.

157 Stapleton $2019 \mathrm{~B}, 22$.

158 Stapleton 2019B, 18.

159 Ray 2015, 348.
} 
of 'wartime masculinity.'160 Regardless of how long it survived in peacetime, wartime propaganda and the rhetoric of the Allied war effort also contributed to a specifically militarised masculinity of, what Korieh terms, 'the 'soldier hero." The degree to which such gendered subjectivities nourished the anger and grievances of ex-servicemen, as well as the wartime prestige of all those who could pass themselves off as 'soldiers,' constitutes an intriguing gendered addition to long-standing debates about war veterans, or the recurrent tendency of non-combatant military labourers to assert their identity as 'soldiers.'

World War Two triggered an intensification of West Africans' connections to the outside world; this global history of the region during the war has appeared in research on African Americans in Africa, as well as on West African soldiers and travellers in Asia, Europe, North America, and the Middle East. The wartime world facilitated the forging and intensification of intellectual, cultural, material, affective, religious, and even linguistic relationships between West Africa and other continents. Many of these did not survive the end of the war, but that does not detract from their historical significance during the war years; some influences proved longer standing, such as the memories of soldiers who visited Jerusalem, wartime students in the U.S.A., and West African journalists in the United Kingdom and Asia. ${ }^{161}$ If, as Crowder contended, local and regional studies still remain important to our understanding, so too do transregional analyses; while core subjects such as recruitment are still of vital importance, newer themes including gender, culture, and religion, take the study of World War Two in West Africa forward into the future.

\section{Bibliography}

\section{Unpublished Sources}

Alozie, B. (2019) 'A Privileged Communicative Space: Nigerian Soldiers' Petitions During the Two World Wars,' Unpublished Conference Paper presented at the Twelfth Annual Association for the Study of the Middle East and Africa Conference, Washington D.C., 31st October to 2nd November.

Coates, O., (2018D), 'From Cairo to Jerusalem: West Africans in the Middle East during the Second World War,' Paper presented at the conference 'Colonial mobilization

16 o Korieh 2020, 334.

161 Coates 2019. 
in Africa and Asia during the Second World War: Soldiers, labourers, and women,' Kyoto University, Japan, 22-23rd March.

Holbrook. W., (1978), The Impact of the Second World War on the Gold Coast: 1939-1945, Unpublished PhD Thesis, Princeton University.

Killingray, D. (1982C), The Colonial Army in the Gold Coast: Official Policy and Local Response, 1890-1947, Unpublished PhD Thesis, School of Oriental and African Studies.

Mizobe. Y., (2018), 'How did the Japanese describe unintended encounters with African soldiers during World War Two - a preliminary report based on contemporary writings and memoirs written in Japanese,' Paper presented at the conference 'Colonial mobilization in Africa and Asia during the Second World War: Soldiers, labourers, and women,' Kyoto University, Japan, 22-23rd March.

Thomas, C. (1986), Colonial Government Propaganda and Public Relations and the Administration in Nigeria, 1939-1951, Unpublished PhD Thesis, Cambridge University.

\section{Published Sources}

Abayomi, D. and R. Oluwafunminiyi. (2019), "Fighting for Britain: Examining British Recruitment Strategies in Nigeria." In. Unknown Conflicts of the Second World War: Forgotten Fronts, C. Murray (ed.), Abingdon: Routledge.

Abdulkadir, D. The Poetry, Life, and Opinions of Sa'adu Zungur. Zaria: The Northern Nigerian Publishing Company, 1974.

Aderinto, S. (2014), 'Isaac Fadoyebo at the Battle of Nyron: African Voices of the First and Second World Wars, ca. 1914-1945, In. African Voices of the Global Past: 1500 to the Present, ed. T. Getz (ed.), Boulder: Westview Press, 107-138.

Agbodeka, F. (1992), An Economic History of Ghana from the Earliest Times. Accra: Ghana Universities Press.

Ajayi, A. (2020), 'Contribution to Britain's War Effort in Osun Division of Western Nigeria, 1939-1945,' Journal of African Military History, 4:1-2.

Amadi, L. (1977-1987), "The Reactions and Contributions of Nigerians During the Second World War: Agents of Political Integration in Nigeria, 1939-1945." Transafrican Journal of History 6/7, 1-11.

Amenumey, D.E.K.(2008), Ghana: A Concise History from Pre-Colonial Times to the 2oth Century. Accra: Woeli Publishing Services.

Ariyo, J.O., (1957), Oju Mi Ri Ni India. London: Longman.

Asante S. (1974), The Italo-Ethiopian conflict: A case study of British West African response to crisis diplomacy in the 1930s. The Journal of African History 15(2), 291302.

Babatunde, R. (2012), 'Bombay's Republic,' In. African Violets and Other Stories: The Caine Prize for African Writing 2012. Oxford: New Internationalist. 
Bandele-Thomas, B. (2007), Burma Boy. London: Jonathan Cape.

Barkawi, T, (2017), Soldiers of Empire: Indian and British Armies in World War II. Cambridge: Cambridge University Press.

Bruce, I. (2013), “They put us in boots: The Queen's Own Cameron Highlander's \& 1st Battalion The Gold Coast Regiment," Great Britain: Keith Steward.

Bruce, I. (2014), 'They Put Us into Boots, the 1st Battalion the Gold Coast Regiment in the East Africa campaign 1940-1941,' Journal of the R.W.A.F.F., 1:6, 238-265.

Bychou, O. (2020), 'Irregular Moroccan Units in a Regular War: Second World War Franco-American Views of the Moroccan Goums Revisited,' Journal of African Military History, 4:1-2.

Byfield, J. (2007), "Feeding the Troops: Abeokuta (Nigeria) and World War II." African Economic History 35, 77-87.

Byfield, J. (2015A). 'Preface,' In. C. Brown, T. Parsons, and A. Sikainga, Africa and World War II, Cambridge: Cambridge University Press.

Byfield, J. (2015B) "Women, Rice, and War: Political and Economic Crisis in Wartime Abeokuta." In. Africa and World War II, J. Byfield, C. Brown, T. Parsons and A. Sikainga (eds.), Cambridge: Cambridge University Press, 147-165.

Chuku G. (2010) 'Crack Kernels, Crack Hitler': Export production drives and Igbo women during the Second World War. In. Gendering the African Diaspora: Women, Culture and Historical Change in the Caribbean and Nigerian Hinterland. Byfield J., LaRay D., and Morrison A. (eds.), Bloomington: Indiana University Press, 219244.

Clarke, P. (1986), West Africans at War 1914-1918 1939-1945: Colonial Propaganda and Its Cultural Aftermath. London: Ethnographica.

Coates, O. (2016), "Narrative, time, and the archive in an African Second World War memoir: Isaac Fadoyebo's 'A Stroke of Unbelievable Luck,'” Journal of Commonwealth Literature, 51 (3), 371-386.

Coates, O. (2017), "Remembrance Day, the Colonial Press and 'Deserving Ex-Servicemen' in Late-Colonial Nigeria." In. An Imperial World at War: Aspects of the British Empire's War Experience, 1939-1945, A. Jackson, Y. Khan and G. Singh (eds.), Abingdon: Routledge, 211-229.

Coates, O. (2018A). “"The War, Like the Wicked Wand of a Wizard, Strikes Me and Carry Away All That I Have Loved:" Soliders' Family Lives and Petition Writing in Ijebu, Southwestern Nigeria, 1943-1945." History in Africa 45, 71-97.

Coates, O. (2018B), "Between Image and Erasure: Photographs of West African Soldiers in India, 1944-1946." Radical History Review 132, 200-207.

Coates, O. (2018C), "World War II and West African Soldiers in Asia." In. Exploitation and Misrule in Colonial and Postcolonial Africa, K. Kalu and T. Falola (eds.), Basingstoke: Palgrave Macmillan, 191-216.

Coates, O. (2019), "Nigeria and the World: War. Nationalism, and Politics, 1914-196o." 
In. The Oxford Handbook of Nigerian Politics A.C. Levan and Patrick Ukata (eds.), Oxford: Oxford University Press, 699-713.

Coates, O. (2020), 'The Threat of Aerial Bombing in World War Two Lagos, 1938-1943,' Journal of African Military History, 4:1-2.

Cole, F. (2013), 'Civil-Military Relations in Colonial Sierra Leone: The Sierra Leone Battalion and the Crisis of Role Perspectives, 1901-1959,' Research in Sierra Leone Studies, Weave $1: 2,1-32$.

Cole, F. (2014), 'Defining the 'flesh' of the black soldier in colonial Sierra Leone: background to the gunners' mutiny of 1939,' Canadian Journal of African Studies, 48:2, $275^{-295}$.

Costello, R. (2012), Black Salt: Seafarers of African Descent on British Ships. Liverpool: Liverpool University Press.

Crowder, M. (1968), West Africa under Colonial Rule. London: Hutchinson.

Crowder, M. (1973) “The 1939-1945 War and West Africa." In A History of West Africa, J.F.A. Ajayi and M. Crowder (eds.), New York: Columbia University Press, 596622.

Crowder, M. (1984), "The Second World War: Prelude to Decolonisation in Africa." In. The Cambridge History of Africa Volume 8, from C. 1940 to C. 1975, M. Crowder (ed.), Cambridge: Cambridge University Press, 8-51.

Crowder, M. (1985), "World War II and Africa: Introduction," Journal of African History 26:4, 287-288.

Crowder, M. (1987), 'Africa and the Second World War by David Killingray and Richard Rathbone; West Africans at War 1914-1918, 1939-1945: Colonial Propaganda and Its Cultural Aftermath by Peter B. Clarke' [Review article], African Affairs 86:344 435438.

Doron, Roy, and Charles Thomas. (2019), "Introducing the New Lens of African Military History." Journal of African Military History 3, 79-92.

Dumett R. (1985) 'Africa's strategic minerals during the Second World War.' Journal of African History 26:4, 381-408.

Ewa, I.O. (1993) 'Military Recruitment in Eastern Nigeria During the Second World War,' Ife Journal of History, 1:1, 32-46.

Fadoyebo, I. (1999) A Stroke of Unbelievable Luck, Madison: African Studies Program, University of Wisconsin Maidson.

Falola T. (1989) 'Cassava starch for export in Nigeria during the Second World War.' African Economic History 18, 73-98.

Falola T. (1992) 'Salt is gold': The management of salt scarcity in Nigeria during World War II. Canadian Journal of African Studies 24:3. 412-436.

Gadsden, F. (1986), 'Wartime Propaganda in Kenya: The Kenya Information Office, 1939-1945,' International Journal of African Historical Studies, 19:3, 401-420.

Gennaro, M. (2020), " "The Cause is a Worthy One, So Come Along with Your Sixpence 
and Enjoy Yourselves with One Hour of Lusty Sport": Sport in Lagos, Nigeria during wWII,' Journal of African Military History, 4:1-2.

Graham, R. (1985), 'There was a Soldier: The Life of Hama Kim M.м.,' Africa Marburgensia 10, 5-35.

Green-Simms, L., (2017), Postcolonial automobility: car culture in West Africa, Minneapolis: University of Minnesota Press.

Hamilton, J. (2001), War Bush: 81 (West African) Division in Burma, 1943-1945. Norwich: Michael Russell.

Haywood A. and F. Clarke. (1964), The history of the Royal West African Frontier Force. Aldershot: Gale \& Polden.

Headrick, R. (1978), "African Soldiers in World War II," Armed Forces and Society, 4:3, $5^{\mathrm{O}}-5^{26}$.

Healey, M. (1999) “"The Polish White Infusion”: Polish Officers in Britain's Royal West African Frontier Force, 1914-1945,' The Polish Review 44:3 (1999), 277-293.

Hidalgo, D. and M. Wélé. (2018), 'Les dockers dakarois. L'organisation du travail dans un port ouest-africain, 1910-199os,' Canadian Journal of African Studies, 52:2, 183-203.

Holbrook, W., (1982), 'Oral History and the Nascent Historiography for West Africa and World War II: A Focus on Ghana,' International Journal of Oral History, 3:3, 148166.

Holbrook, W. (1985), "British Propaganda and the Mobilization of the Gold-Coast War Effort, 1939-1945." Journal of African History 26: 4, 347-361.

Howard, A. (2015), "Freetown and World War II: Strategic Militarization, Accommodation, and Resistance." In. Africa and World War II, J. Byfield, C. Brown, T. Parsons and A. Sikainga (eds.), Cambridge: Cambridge University Press, 183-199.

Ibhawoh B. (2007), Second World War propaganda, imperial idealism and anti-colonial nationalism in British West Africa. Nordic Journal of African Studies 16:2: 1-17.

Igbino, J. (2018), Spidermen: Nigerian Chindits and Wingate's Operation Thursday, Burma 1943-1944. Bloomington: AuthorHouse U.K.

Israel, A.M. (1992), "Ex-Servicemen at the Crossroads-Protest and Politics in Postwar Ghana." Journal of Modern African Studies 30: 2, 359-368.

Jackson, A. (2006), The British Empire and the Second World War. London: Hambledon Continuum.

Jackson, A., (2018), Of Islands, Ports, and Sea Lanes. Warwick: Helion.

Jeffery, K. (2011), M.I.6: The History of the Secret Intelligence Service, 1909-1949. London: Bloomsbury.

Jennings, E., (2015), Free French Africa in World War II: the African resistance. Cambridge: Cambridge University Press.

Jesman, C. (1965), The "Polish Experiment" in West Africa During World War Two, Africa: Rivista trimestrale di studi e documentazione dell'Istituto italiano per l'Africa e l'Oriente, 20:4, 413-426. 
Keazor, Ed (dir.) (2019), Company Yaya: Lost African Voices of World War 2, Nigeria, 41 mins.

Kerslake, R. (1997), Time and the Hour: Nigeria, East Africa, and the Second World War, Radcliffe Press: London.

Killingray D. (1979), 'The Idea of a British Imperial African Army,' Journal of African History, 20:3, 421-436.

Killingray D., and R. Rathbone, (1982A), 'Introduction,' In. Africa and the Second World War, D. Killingray and R. Rathbone (eds.), Basingstoke: Macmillan, 1-19, 1.

Killingray, D. (1982B), "Military and Labor Recruitment in the Gold Coast During World War 2." Journal of African History 23:1, 83-95.

Killingray, D. (1983), The British Military Presence in West Africa. Oxford Development and Records Project Report. Oxford: Rhodes House Library.

Killingray, D. (1994), “The 'Rod of Empire': The Debate over Corporal Punishment in the British African Colonial Forces, 1888-1946," Journal of African History 35 (2), 201-216.

Killingray, D. (1996), "African and African Americans in enemy hands," In. Prisoners of War and their Captors in World War II, B. Moore and K. Fedorovich (eds.), Oxford: Berg, 181-204.

Killingray, D. (1997), "'If I Fight for Them, Maybe Then I Can Go Back to the Village": African Soldiers in the Mediterranean and European Campaigns, 1939-1945,' In. P. Addison and A. Calder (eds.), Time to Kill: The Soldier's Experience of War in the West, London: Picador, 93-114.

Killingray, D. (2001), "African voices from two worlds wars," Historical Research 74:186, 425-443.

Killingray, D. (2010), Fighting for Britain:African Soldiers in the Second World War. Woodbridge: James Currey.

Killingray, D. (2016), "British Racial Attitudes Towards Black People During the Two World Wars". In Colonial Soldiers in Europe, 1914-1945: 'Aliens in Uniforms' in Wartime Societies. E. Storm and A. Tuma (eds.), London: Routledge, 97-118.

Korieh, C. (2010) “"May It Please Your Honor”: Letters Of Petition As Historical Evidence In An African Colonial Context,' History in Africa, 37, 83-106.

Korieh C. (2014) Life Not Worth Living: Nigerian Petitions Reflecting on African Society's Experience During World War II. Durham, NC: Carolina Academic Press.

Korieh C. (2020), Nigeria and World War II: Colonialism, Empire, and Global Conflict. Cambridge: Cambridge University Press.

Lambo, R. (1994), "Achtung! The Black prince: West Africans in the Royal Air Force, 1939-1946" In. Africans in Britain, D. Killingray (ed.), London: Cass., 145-163.

Lanning E., (2013) 'The honours \& Awards to the 24th (Gold Coast) Infantry Brigade for the East Africa campaign, 1940-1,' Journal of the RWAFF, 1:4, 146-149.

Lawler, N. (1997), 'The Crossing of the Gyaman to the Cross of Loraine:Wartime Politics in West Africa, 1941-1942,' African Affairs, 96:348, 53-71. 
Lett, B. (2012), Ian Fleming and s.o.E.'s Operation Postmaster, Barnsley: Pen \& Sword. Mann, G., (2006), Native Sons: West African Veterans and France in the Twentieth Century. Durham: Duke University Press.

Mazrui A. (1985) 'Africa and the legacy of the Second World War: Political, economic and cultural aspects,' In. Africa and the Second World War: Report and Papers of the Symposium Organised by U.N.E.S.C.O. at Benghazi, Libyan Arab Jamahiriya, from 10 to 13 November 1980 , U.N.E.S.C.o. (ed.), Paris: U.N.E.s.C.o., 13-25.

Mizobe, Y. (2012), "The African Press Coverage of Japan and British Censorship During World War II - a Case Study of the Ashanti Pioneer, 1939-1945." Tinabantu:Journal of African National Affairs 4:2, 26-36.

Mizobe, Y. (2015), "Japanese Newspaper Coverage of Africa (and African Soldiers) During World War II: The Case of the Tokyo Nichi Nichi (Mainichi) Shimbun, 19391945." In. Ethnicities, Nationalities, and Cross-Cultural Representations in Africa and the Diaspora, G. Chuku (ed.), Durham: Carolina Academic Press, 174-175.

Mordi, E. (2002), 'The role of the Nigerian press in the industrial relations process in colonial Nigeria, 1940-1945: A historical perspective.' African Journal of Economy and Society 4:1-2, 22-26.

Mordi, E. (2017A), 'Imperial Britain and the challenge of press freedom in Nigeria during the Second World War,' Journal of Development and Communication Studies 5:1, 98-121.

Mordi E. (2017B), 'In Defense of Empire: Government Press Collaboration in the British Win the War Efforts in Nigeria During the Second World War', Jebat: Malaysian Journal of History, Politics \& Strategic Studies, 44:1, 58-88.

Mordi, E. (2019A). "What If the Huns Come? Imperial Britain's Attitude Towards Nigerians." Asian and African Studies 56: 6: 838-857.

Mordi, E. (2019B): "Nigerian Forces Comforts Fund, 1940-1947: The Responsibility of the Nigerian Government to Provice Funds for the Welfare of Its Soldiers" Itinerario $43: 3516-542$.

Mordi, E. (2020A), “'No Longer Required for Operations': Troops' Repatriation to West Africa after the Second World War, 1945-1950." Journal of Imperial and Commonwealth History DoI: $10.1080 / 03086534.2020 .1765536$.

Mordi, E. (2020B), “'Forward Petitions to Newa for Whatever Guidance and Assistance, If Any': Post-War Demobilisation Conundrum in Nigeria, 1946-1951." Journal of Asian and African Studies 55:4, 586-599.

Mordi, E. (2020C), 'Recruitment of Nigerians for Military Service during the Second World War, 1939-1945,' Journal of the Society for Army Historical Research, 98, 276303 .

Mordi, E. (2020D), "We Cannot Suffer in Burma and Return to Face Trials In Our Own Country": Demobilization of Nigerian Soldiers, 1943-1953, Journal of African Military History, 4:1-2. 
Morris, K. (2000), British Techniques of Public Relations and Propaganda for Mobilizing East and Central Africa during World War II Lewiston: Edwin Mellen.

Morrow, J. (2010), "Black Africans in World War II: The Soldiers' Stories." Annals of the American Academy of Political and Social Science 632, 12-25.

Mullen, J, and S. Newell (2008). "An Extract from 'My Experience in Cameroons During the War." Africa 78: 3, 401-409.

Newell, S. (2008), "An Introduction to the Writings of J.G. Mullen, an African Clerk, in the Gold Coast Leader, 1916-1919." Africa 78:3, 384-40o.

Njoku O. (1977-1978) The burden of imperialism: Nigeria war relief fund, 1939-1945. Transafrican Journal of History 6-7, 79-99.

Nwaka, G. (1987), "Rebellion in Umuahia, 1950-1951: Ex-Servicemen and Anti-Colonial Protest in Eastern Nigeria." Transafrican Journal of History 16, 47-62.

Olomola, I. (1976) "The Demobilization of Nigerian Troops 1946-1950: Problems and Consequences." Odu 13, 40-59.

Olukoju, A. (2002), "Buy British, Sell Foreign: External Trade Control Policies in Nigeria During World War II and Its Aftermath, 1939-1950." International Journal of African Historical Studies 35, 363-384.

Olusanya, G.O. (1968), "The Role of Ex-Servicemen in Nigerian Politics.” The Journal of Modern African Studies, 6: 221-232.

Olusanya, G. (1973), The Second World War and politics in Nigeria, 1939-1953, London: Evans Brothers.

Owen, O., (2O20), 'World War Two, song, and popular culture in Northern Nigeria,' Journal of African Cultural Studies, forthcoming.

Parsons, T. (1999), The African Rank-and-File: SocialImplications of Colonial Military Service in the King's African Rifles, 1902-1964. Portsmouth: Heinemann.

Parsons, T. (2015), "No Country Fit for Heroes: The Plight of Disabled Kenyan Veterans." In. Africa and World War II, J. Byfield, C. Brown, T. Parsons and A. Sikainga (eds.), Cambridge: Cambridge University Press, 127-148.

Parsons, T. (2017), "Mau Mau's Army of Clerks: Colonial Military Service and the Kenya Land Freedom Army in Kenya's National Imagination." Journal of African History 58:2, 285-309.

Phillips, B. (2014), Another Man's War: The Story of a Burma Boy in Britain's Forgotten African Army. London: Oneworld.

Prah, E. (2014), 'The 5oth Anniversary of the crossroads shooting incident in front of Christiansborg Castle on the 28th February 1948 (part 1), Journal of the RWAFF, 1:6, 232-237.

Prah, E. (2016), 'The 5oth Anniversary of the crossroads shooting incident in front of Christiansborg Castle on the 28th February 1948 (part 3), Journal of the RWAFF, 1:8, 359-362.

Preprah-Gyamfi, R. (2018), World War II Revisited-Memoirs of a Forced African Conscript, Perseverance Books: Loughborough. 
Ray, C. (2015), "World War II and the Sex Trade in British West Africa." In. Africa and World War II, J. Byfield, C. Brown, T. Parsons and A. Sikainga (eds.), Cambridge: Cambridge University Press, 339-358.

Ray, D., (1975), "The Takoradi Route: Roosevelt's Prewar Venture Beyond the Western Hemisphere." Journal of American History 62: 2, 340-358.

Rayment, J. (2003), Temporary Gentlemen: 'Sapper' Field Company, 81st Division Royal West African Frontier Force Burma Campaign, 1943-1945, George Mann: Winchester.

Roger Louis, W. (1986), 'India, Africa and the Second World War,' Ethnic \& Racial Studies 9:3, 306-320.

Ross, S. (1983) Stepping Stones: Memoirs of Colonial Nigeria, 1907-196o, London: Owen.

Roy, K. (2010), "Discipline and Morale of the African, British and Indian Army Units in Burma and India During World War II: July 1943 to August 1945." Modern Asian Studies 44:6, 1255-1282.

Schler, L. (2009), “Transnationalism and Nationalism in the Nigerian Seamen's Union.” African Identities 7:3, 387-398.

Schler, L. (2018), Nation on Board: Becoming Nigerian at Sea. Athens: Ohio University Press.

Sikainga, A. (2015), "Conclusion: Consequences of the War." In. Africa and World War II, J. Byfield, C. Brown, T. Parsons and A. Sikainga (eds.), Cambridge: Cambridge University Press, 501-5o8.

Smyth, R. (1984), 'War Propaganda During the Second World War in Northern Rhodesia,' Africa Affairs, 83, 345-358.

Stanley, W. (1994), “Trans-South Atlantic Air Link in World War II." GeoJournal 33: 4. $459-463$.

Stapleton, T. (2013), A Military History of Africa, Volume 2: The Colonial Period: From the Scramble for Africa to the Algerian Independence War (ca. 1870-1963). Santa Barbara: Praeger.

Stapleton, T. (2019A), 'Martial Identities in Colonial Nigeria.' Journal of African Military History 3: 1, 1-32.

Stapleton, T. (2019B), "Barracks Islam and Command Christianity: Religion in Britain's West African Colonial Army (C. 1900-196o)." War \& Society 39:1, 1-22.

Steward, K. (2012), 'Major Seth Anthony мве, the First African soldier to receive the King's Commission in the Royal West African Frontier Force in 1942,' Journal of the R.W.A.F.F., 1:2, 69-71.

Stewart A (2017) 'The Second World War and the 'quiet colony of Sierra Leone.' In. Jackson A, Khan Y and Singh G (eds.) An Imperial World at War: The British Empire, 1939-1945. London: Routledge, pp. 10-29.

Stewart, A. (2016), The First Victory: The Second World War and the East Africa Campaign. New Haven: Yale University Press.

Thomas, R. (1973), 'Forced Labour in British West Africa: The Case of the Northern Territories,' Journal of African History, 14:1, 79-103. 
Ubah, C. (1998), Colonial Army and Society in Northern Nigeria. Kaduna: National Defence Academy.

Ukpabi, S. (1987), The Origins of the Nigerian Army: A History of the West African Frontier Force 1897-1914. Zaria: Gaskiya Corporation.

Yao, K. (1993), La Côte d' Ivoire Pendant La Seconde Guerre Mondiale Entre Fidélité et Rupture (1939-1945) Africa: Rivista trimestrale di studi e documentazione dell'Istituto italiano per l'Africa e l'Oriente, 48:4, 549-576. 